\title{
Phytochemical Screening and Pharmacological Examination of Persia Americana Mill (Avocado) Crude Seed Extracts
}

\author{
Gangadhara Angajala, Valmiki Aruna, Radhakrishnan Subashini, Geetha Das, Ramanathan \\ Rajajeyaganthan
}

\begin{abstract}
In the present study crude seed extracts of Persia Americana Mill (Avocado) was prepared using petroleum ether, methanol, ethyl acetate and aqueous solvents. The phytochemical screening of different crude extracts were studied for the presence of alkaloids, carbohydrates, protein, phenols, tannins, saponin, triterpenoids, glycosides, phytosterols, gums and mucilage. The crude seed extracts were pharmacologically evaluated for its antiinflammatory efficacy. The results obtained clearly demonstrated that out of the screened crude extracts, petroleum ether extract possess better pharmacological activities. From the GC-MS and FTIR analysis of petroleum ether extract 5 major compounds were identified and considered to play a key role in the overall pharmacological efficacy of avocado seed extract.
\end{abstract}

Keywords: Persea Americana Mill, Avocado, Antiinflammatory.

\section{INTRODUCTION}

Plants have been part of our lives since the beginning of time and in recent years natural products has gained attention in the field of medicine [1-3]. Plants play a vital role in humans as they possess several active constituents which are the precursors for the synthesis of many drugs [4-8]. The practices and philosophy of various traditional medicine systems are highly influenced by the geographical area, environmental factors and their associated prevailing conditions [9-11]. Medicinal plants form the main support of traditional system of medicine all over the world mainly by the utilization of numerous plants and plant derived products to care and relief from various physical and mental illness [12-14]. The importance of traditional medicine and its

Revised Manuscript Received on December 05, 2019

* Correspondence Author

Gangadhara Angajala*, Chemistry, Kalasalingam Academy of Research and Education, Krishnankoil, Virudhunagar, India.

Email: gangadharaangajala@gmail.com

Valmiki Aruna, Chemistgry, Kalasalingam Academy of Research and Education, Krishnankoil, Virudhunagar, India.

Email: aruna.prahan@gmail.com

Radhakrishnan Subashini, Chemistry, Arignar Anna Government Arts College for women, Walajapet-632513, India.

Email: dr.subashini.r@gmail.com

Geetha Das, Chemistry, Kalasalingam Academy of Research and Education, Krishnankoil, Virudhunagar, India.

Email: geethachem2015@gmail.com

Ramanathan Rajajeyaganthan, Chemistry, Kalasalingam Academy of Research and Education, Krishnankoil, Virudhunagar, India.

Email: rajajeyaganthan.r@klu.ac.in utilization is increasing dramatically all over the world because it is more affordable and easily allows maximum public access to health information [15-16]. Phytomedicines are also important for drug discovery and development especially as starting materials in the synthesis of pharmacologically active drugs [17-18].

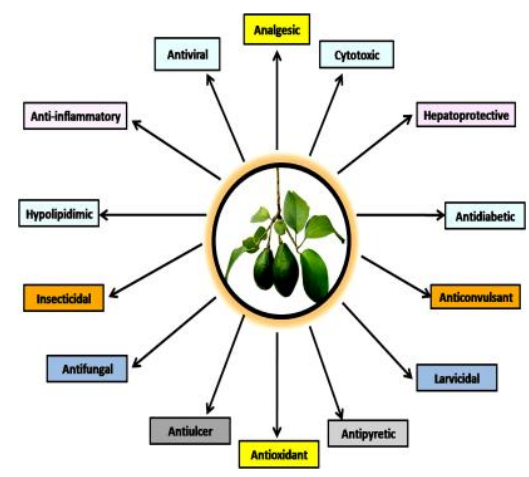

Fig.1. Various pharmacological activities of Persea americana Mill

Persia Americana Mill (Avocado) is generally distributed nearly in almost all parts of the tropical and subtropical regions with suitable environmental conditions [20]. It belongs to the family lauraceae and commonly known as alligator pear, reflecting its shape and leather like appearance of the skin. Avocado is the most nutritious among all seeds and is regarded as the most important contribution of the new world to human diet. Avocado possess many pharmacological activities and generally used for the treatment of various diseases [21] [Fig.1]. Avocado is considered as an evergreen plant although some varieties lose their leaves before flowering for short period of time. In the present work crude seed extracts of avocado were isolated using petroleum ether, methanol, ethyl acetate and aqueous solvents. The extracted crude isolates were evaluated for its antiinflammatory efficacy.

\section{MATERIALS AND METHODS}

\section{A. Collection of plant material}

The Avocado seeds were collected from Sholinghur area $\left(12.9275^{\circ} \mathrm{N}, 79.3302^{\circ} \mathrm{E}\right)$ Vellore district, Tamil Nadu, India.

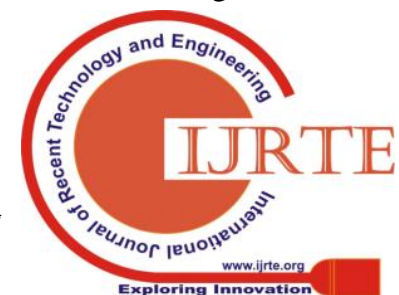




\section{B. Extraction and isolation}

Fresh seeds of Avocado were taken and thoroughly washed by using distilled water. The seeds were finely powdered after drying in a shade region for six days. A weighed quantity of powdered drug (100 g) was taken and packed in a Soxhlet extractor using different solvents (petroleum ether, methanol, ethyl acetate and aqueous solvents) extracts were prepared accordingly.

\section{Phytochemical screening}

Phytochemical screening were carried out for different seed extracts of avocado as per the standard methods [22-23].

\section{In-vitro antiinflammatory studies}

In the present work in-vitro anti-inflammatory studies were carried out by two methods as per the reported method [2425].

\section{- Membrane stabilization activity}

- Proteinase inhibitory activity

RBCs membrane was studied as it was closely similar to lysosomal membrane. At the location of inflammation the release of lysosomal content is inhibited because of the heat induced hemolysis. The extracellular release of neutrophil lysosomal constituents which include protease and bacterial enzymes can further initiates tissue damage which leads to inflammation. Proteinase has been associated in arthritic reaction. Lysosomal granules of the neutrophils possess many serine proteinases which play a prominent role in the progression of several inflammatory reactions through tissue damage. Therefore by employing proteinase substantial level of protection was provided by proteinase inhibitors during inflammatory processes.

\section{RESULTS AND DISCUSSION}

\section{A. Phytochemical Screening}

The phytochemical test results of different avocado seed extracts are shown in Table-I. Proteins, carbohydrates and phytosterols are present in all the four seed extracts. Ethyl acetate extract of avocado seed contain flavonoids, glycosides and saponins. Terpenoids are commonly present in methanol and petroleum ether extracts whereas alkanols are present in petroleum ether extract. Terpenoids and alkanols furnish to analgesic and anti-inflammatory activities. Aqueous extract contains tannins, flavonoids and saponins. Terpenoids and saponins function as regulators of mechanism and play a protective role as an antioxidant. They are able to form a hydro-peroxide intermediate, thus preventing cell damages by free radicals.

TABLE-I: Preliminary phytochemical studies of avocado seed extracts

\begin{tabular}{llcccc}
\hline & & \multicolumn{5}{c}{ Samples } \\
\cline { 3 - 6 } S.No & $\begin{array}{l}\text { Phytochemical } \\
\text { constituents }\end{array}$ & $\begin{array}{l}\text { Pet ether } \\
\text { extract }\end{array}$ & $\begin{array}{l}\text { Methanol } \\
\text { extract }\end{array}$ & $\begin{array}{l}\text { Ethyl acetate } \\
\text { extract }\end{array}$ & $\begin{array}{l}\text { Aqueous } \\
\text { extract }\end{array}$ \\
\hline 1 & Alkaloids & - & + & - & + \\
2 & Carbohydrates & + & + & + & + \\
3 & Proteins and & + & + & + & +
\end{tabular}

\begin{tabular}{|c|c|c|c|c|c|}
\hline & $\begin{array}{l}\text { free amino } \\
\text { acids }\end{array}$ & & & & \\
\hline 4 & Phytosterols & + & + & + & + \\
\hline 5 & Alkanols & + & - & - & - \\
\hline 6 & Tannin & - & + & - & + \\
\hline 7 & Flavonoids & - & + & + & + \\
\hline 8 & Triterpenoids & + & + & - & - \\
\hline 9 & Glycosides & - & + & + & - \\
\hline 10 & $\begin{array}{l}\text { Gums and } \\
\text { mucilages }\end{array}$ & - & - & - & - \\
\hline 11 & Saponins & - & + & + & + \\
\hline
\end{tabular}

( + ) indicates the presence of Chemical Constituents

( - ) indicates the absence of Chemical Constituents

\section{B.Pharmacological evaluation}

The pharmacological screening of crude extracts of avocado shows good antiinflammatory activity. The results obtained from antiinflammatory activity clearly showed that out of the screened crude extracts, petroleum ether extract possess better efficacy with percentage inhibition of $41.20 \pm 0.05$ and $82.13 \pm 0.06$ towards membrane stabilization and proteinase inhibitory activity at a concentration of $100 \mu \mathrm{g} / \mathrm{mL}$ which was comparable to that of standard etodolac $(68.18 \pm 1.66$ and $74.06 \pm 0.07$ ). The aqueous crude extract of avocado showed moderate antiinflammatory efficacy with percentage inhibition of $38.71 \pm 0.07$ and $66.28 \pm 0.09$ respectively (Table-II).

\section{GC-MS Analysis of Petroleum Ether Crude Seed Extract}

Table-III shows the constituents of petroleum ether seed extract of avocado. A total of 5 compounds were identified from GC-MS analysis representing $79.70 \%$ of total composition of seed extract (Fig. 2). The major compounds identified by comparing with the library include 1-hydroxy heneicosa-2,12,15-trien-4-one, 1 (34.18\%), 2-hydroxy -4-oxo henei-cosa-5, 12-dien-1-yl acetate, 2 (26.82 \%) 1,2,4-trihydroxy nonadecane, 3 (14.79\%), 1-hydroxy heneicosa-2,5,12,15 -tetraen-4-one, $4(8.62 \%)$ and 1,2,4-trihydroxy heptadec - 16-ene, 5 (5.29\%). The percentage composition of the remaining compounds ranged from $0.54 \%$ to $1.46 \%$ (Fig. 3-8). These compounds were found to be majorly contributing for bioefficacy of the petroleum ether crude seed extract.

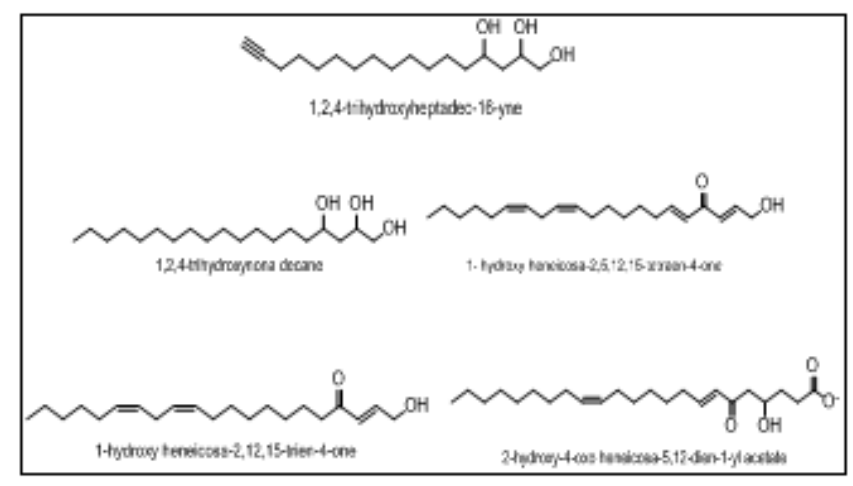

Fig.2. Compounds identified from GC-MS analysis of petroleum ether extract of avocado seeds. 


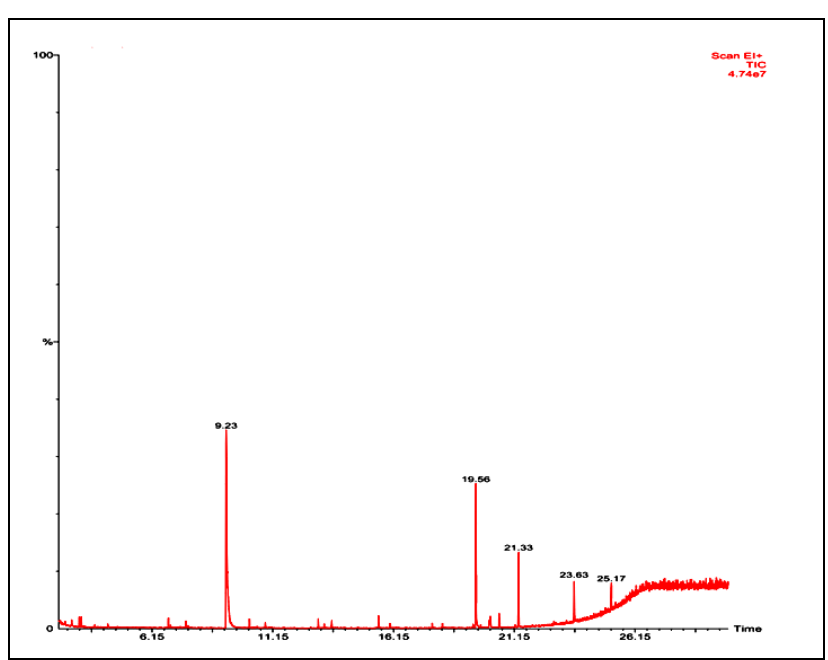

Fig.3. GC-MS showing various retention times of the petroleum ether crude extract

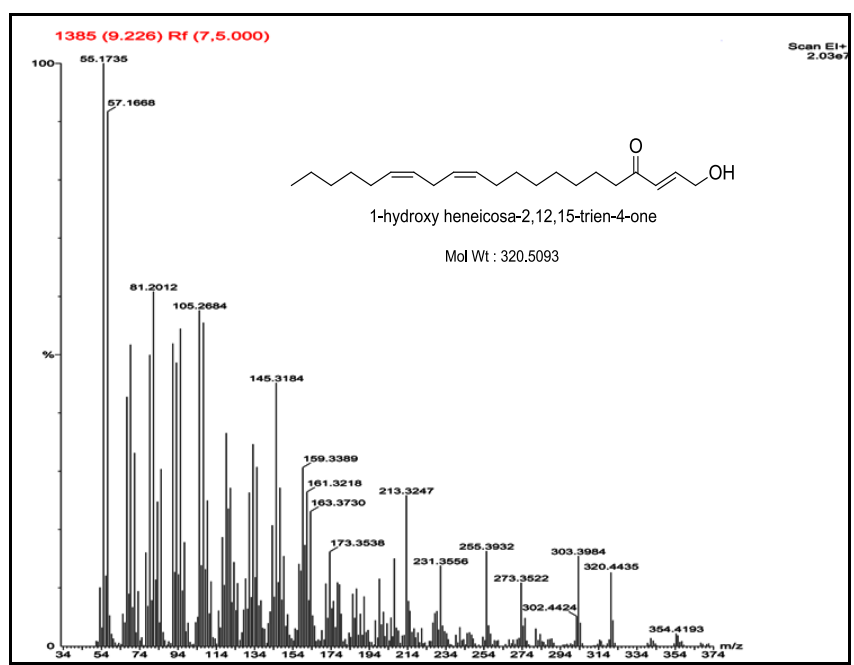

Fig.4. GC-MS spectrum of 1-hydroxy heneicosa-2,12,15trien-4-one

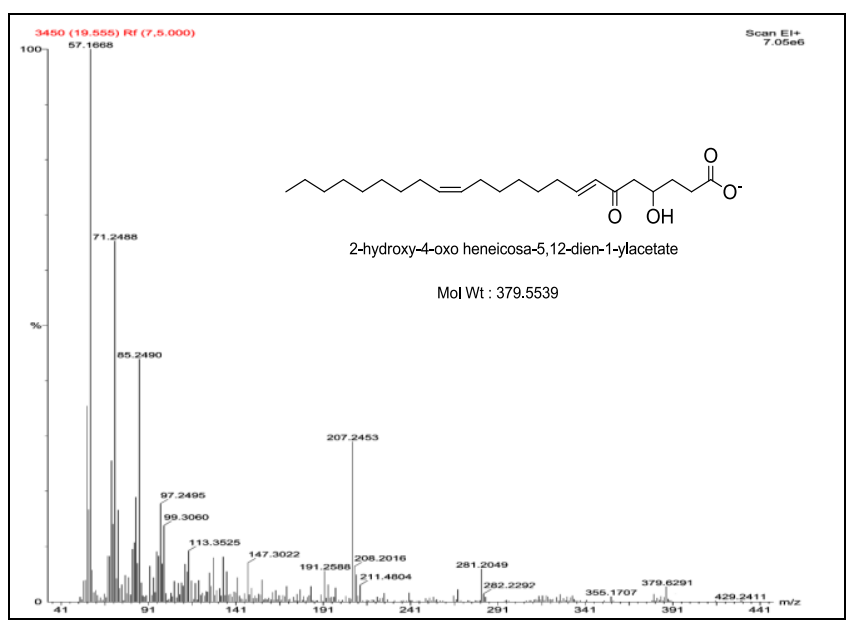

Fig.5. GC-MS spectrum of 2-hydroxy-4-oxo heneicosa-5,12-dien-1-yl acetate

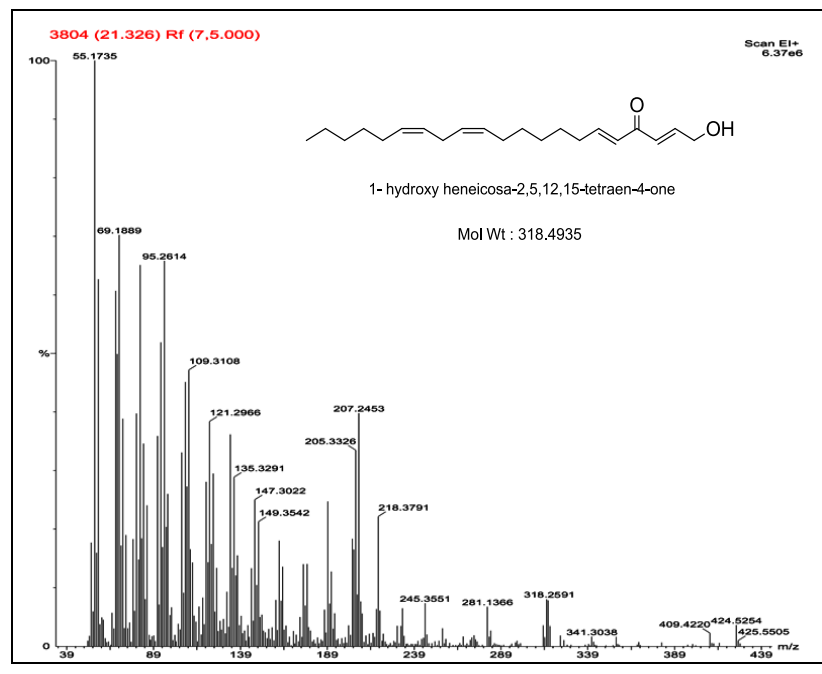

Fig.6. GC-MS spectrum of 1-hydroxy heneicosa-2,5, 12,15- tetraen-4-one

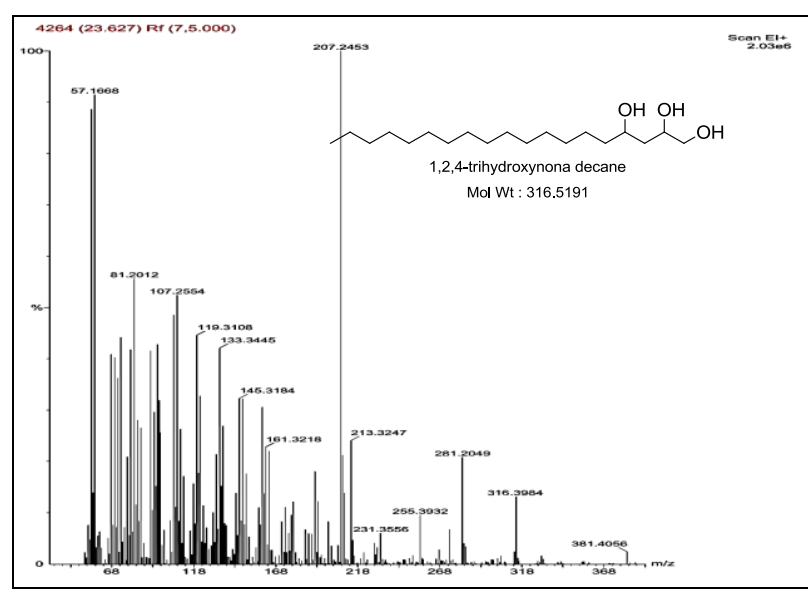

Fig.7. GC-MS spectrum of 1,2,4-trihydroxynonadecane

Table-II: Percentage inhibition for membrane stabilizing and proteinase inhibitory activity of Avocado seed extracts

Percentage inhibition of membrane stabilization studies

\begin{tabular}{cclllll}
\hline S.No & Conc. $(\mu \mathrm{g} / \mathrm{mL})$ & $\begin{array}{l}\text { Aqueou } \\
s\end{array}$ & $\begin{array}{l}\text { Pet } \\
\text { ether }\end{array}$ & Methanol & $\begin{array}{l}\text { Ethyl } \\
\text { acetat } \\
e\end{array}$ & Std $^{a}$ \\
\hline & & & 16.0 & & & \\
\hline & & $13.26 \pm$ & $4 \pm$ & $14.18 \pm$ & 10.14 & $3 \pm$ \\
1 & 25 & 0.16 & 0.21 & 0.21 & \pm 0.92 & 0.15 \\
& & & 28.1 & & & 38.1 \\
2 & 50 & 0.28 & 0.43 & 1.47 & \pm 0.03 & 0.21 \\
3 & 100 & $38.71 \pm$ & 41.2 & $39.61 \pm$ & 33.26 & 64.1 \\
& & 0.07 & $0 \pm$ & 0.36 & \pm 0.19 & $8 \pm$ \\
& & & 0.05 & & & 1.66 \\
\hline
\end{tabular}

Percentage inhibition of proteinase inhibitory studies

\begin{tabular}{|c|c|c|c|c|c|c|}
\hline 1 & 25 & $\begin{array}{l}22.18 \pm \\
0.11\end{array}$ & $\begin{array}{l}35.0 \\
2 \pm \\
0.15\end{array}$ & $\begin{array}{l}30.47 \pm \\
0.04\end{array}$ & $\begin{array}{l}17.05 \\
\pm 1.01\end{array}$ & $\begin{array}{l}29.0 \\
6 \pm \\
0.42\end{array}$ \\
\hline 2 & 50 & $\begin{array}{l}41.02 \pm \\
1.32\end{array}$ & $\begin{array}{l}54.2 \\
2 \pm \\
1.05\end{array}$ & $\begin{array}{l}48.16 \pm \\
1.71\end{array}$ & $\begin{array}{l}25.01 \\
\pm 0.08\end{array}$ & $\begin{array}{l}47.2 \\
1 \pm \\
0.65\end{array}$ \\
\hline
\end{tabular}




\begin{tabular}{lllllll}
3 & 100 & $66.28 \pm$ & 82.1 & $69.14 \pm$ & 40.31 & 74.0 \\
& & 0.09 & $3 \pm$ & 0.02 & \pm 0.64 & $6 \pm$ \\
& & 0.06 & & & 0.07 \\
\hline
\end{tabular}

${ }^{a}$ Etodolac

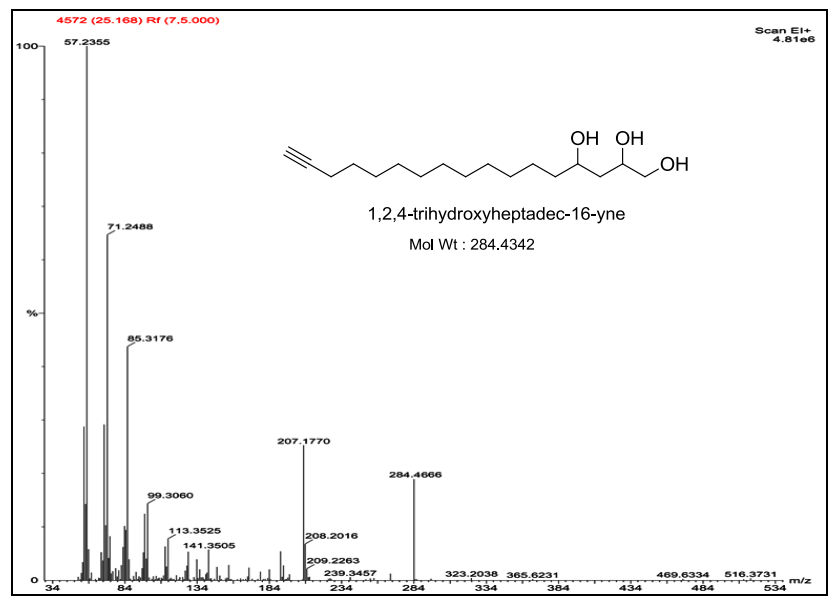

Fig.8. GC-MS spectrum of 1,2,4-trihydroxyheptadec $-16-y n e$

TABLE-III: GC-MS analysis of petroleum ether crude extract

\begin{tabular}{llll}
\hline Compounds & RT & Composition $(\%)$ & MW \\
\hline 1 & 09.23 & 34.18 & 320.27 \\
2 & 19.56 & 26.82 & 379.55 \\
3 & 21.33 & 14.79 & 318.25 \\
4 & 23.63 & 08.62 & 316.29 \\
5 & 25.17 & 05.29 & 284.45 \\
\hline Total & 92.83 & \\
\hline
\end{tabular}

RT-Retention Time; MW: Molecular Weight

\section{FT-IR data for petroleum ether extract of avocado seed}

The FT-IR analysis showed a broad absorption band centered at $3419.79 \mathrm{~cm}-1$ corresponds to the band $\mathrm{O}-\mathrm{H}$ stretching vibrations. The weak band near $1629.85 \mathrm{~cm}-1$ was assigned to bending vibrations of $\mathrm{C}=\mathrm{O}$ bond. The absorption bands serrated in the region $1000-1500 \mathrm{~cm}-1$ are assigned to $\mathrm{C}-\mathrm{O}$ stretching vibrations and $\mathrm{O}-\mathrm{C}=\mathrm{O}$ symmetric and asymmetric stretching vibrations. The band around $734.88 \mathrm{~cm}-1$ corresponds to $\mathrm{C}=\mathrm{O}$ stretching vibrations [Fig. 9].

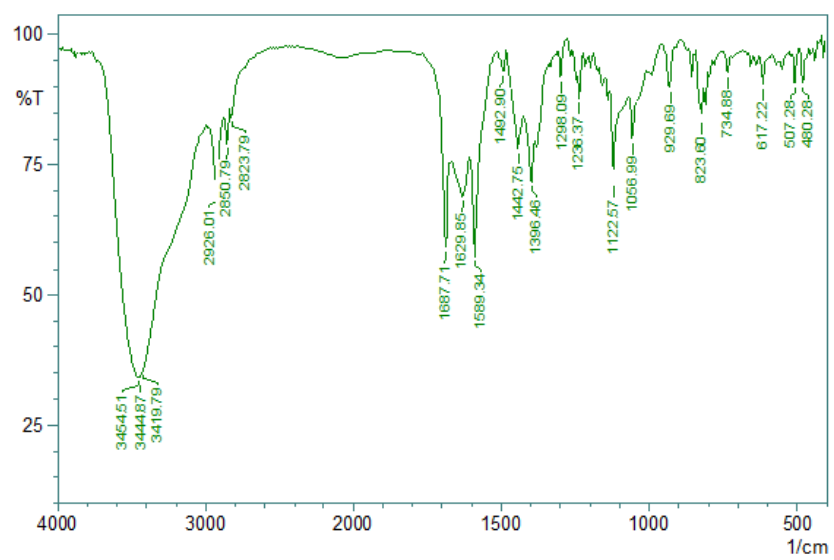

Fig. 9. FT-IR spectrum of petroleum ether crude seed extract of avocado

IV. CONCLUSION
So in the present work phytochemical and pharmacological screening of the crude avocado seed extracts were carried out and the potent molecules responsible for the better activity of petroleum ether crude extract were identified successfully through GC-MS. In future research has to be carried out in order to isolate the active components from crude extracts through column chromatography and thus comparative studies towards pharmacological activities will be done.

\section{ACKNOWLEDGEMENTS}

The authors sincerely thank the management of Kalasalingam Academy of Research and Education, Tamil $\mathrm{Nadu}$, India for their constant encouragement and support and providing all the necessary facilities for carrying out this research work. The authors are grateful to Arulmighu Kalasalingam College of Pharmacy, Krishnankoil for providing necessary facilities and co-operation during this research work.

\section{REFERENCES}

1. C.P. Khare, "Indian Medicinal Plants," Springer International Edition. pp.329-330, 2007.

2. P.K.Chandra, P.D. Pitamber and S.S. Bikram, "Developing the medicinal plants sector in northern India: Challenges and oppurtunities," J Ethnobiol Ethnomed. vol. 62, pp.173-182, 2008.

3. E. Edwin, S.B. Joshi and D.C. Jain, "A brief review on few Indian medicinal plants," Int J Green Pharm. vol.1, pp.2-12, 2007.

4. K. Ashutosh, "Pharacognosy and Pharmaco biotechnology," 2nd edition, New Age International Publishers, New Delhi. pp.5-7, 2007.

5. M. Barrett, "The Hand Book of Clinically Tested Herbal Remedies," 1st edition, CBS Publishers and Distributers, New Delhi. pp.3-6, 2007.

6. C.S.I.R, "The wealth of India," National Institute of Science communication and Information Resources. vol.I, pp.86, 1985.

7. V.S. Agarwal, "Rural economics of medicinal plant: Vegetation in the forest," Drug plants of India, Kalyani publishers India.vol.1, pp.1-160, 1997.

8. M. Yasir, M, Das and M.D. Kharya, "The phytochemical and pharmacological profile of Persea Americana Mill," Phcog Rev. vol.4, pp.77, 2010.

9. N.H. Oberlis, L.L. Rogers, J.L. Martin and J.L. McLaughlin, "Cytotoxic and Insecticidal constituents of the unripe fruit of Persea Americana," J Nat Medicine. vol.61, pp.781-785, 1998.

10. H. Kawagishi, Y. Fukumoto, M. Hatakeyama and P. He, "Aremoto F, Matsuzawa T. Liver injury suppressing compounds from avocado (Persea Americana)," J Agric Food Chem. vol.49, pp.2215-2221, 2001.

11. A.J. Butt, C.G. Roberts, A.A. Seawright, P.B. Oelrichs, J.K. Macleod and T.Y. Liaw et al., "A novel plant toxin, persin, with in vivo activity in the mammary gland, induces Bim-dependent apoptosis in human breast cancer cells," Mol Cancer Ther. vol.5, pp.2300-2309, 2006.

12. C. Rodriguez-Saona, D.F. Maynard, S. Phillips and J.T. Trumble, "Avocado furans and their tetra hydro furan analogues: Comparison of growth inhibitory and insecticidal activity," J Agric Food Chem. vol.48, pp.3642-3645, 2000

13. J.J.G. Leite, E.H.S. Brito, R.A. Cordeiro, R.S.N. Brilhante, J.J.C. Sidrim and L.M. Bertini et al., "Chemical composition, toxicity and larvicidal and antifungal activities of Persea Americana seed extracts," Revista da Sociedade Brasileira de Medicina Tropical. vol.42, pp.110-113, 2009.

14. F. Abe, S. Nagafuji, M. Okawa, J. Kinjo, H. Akahane and T. Ogura et al., "Trypanocidal Constituents in plants. Evaluation of some Mexican plants for their trypanocidal activity and active constituents in the seeds of Persea Americana," Biol Pharm.Bull. vol.28, pp.1314-1317, 2005.

15. O.N. Anaka, R.I. Ozolua and S.O. Okpo, "Effect of aqueous seed extract of Persea american Mill on the blood pressure of Sprague dawley rats," Afr J Pharm Pharmacol. vol.3, pp.485-490, 2009.

16. K.E. Imafidon and F.C. Amaechina, "Effects of Aqueous Seed Extract of Persea Americana Mill. (Avocado) on Blood Pressure and Lipid Profile in Hypertensive Rats,' Advances in Biological Research. vol.4, pp.116-121, 2010 
17. B.S. Antia, J.E. Okokon and P.A. Okon, "Hypoglycemic activity of aqueous leaf extract of Persea americana Mill," Indian J Pharmacol. vol.37, pp.325-326, 2005

18. C.R. Lima, C.F. Vasconcelos, J.H. Costa-Silva, C.A. Maranhao, J. Costa and T.M. Batista, "Anti-diabetic activity of extract from Persea Americana Mill leaf via the activation of protein kinase B (PKB/Akt) in streptozotocin-induced diabetic rats,"J Ethno pharmacol. vol.141, pp.517-525, 2012.

19. D.O. Edem, "Antihyperlipidemic effects of ethanolic extracts of alligator peer seed (Persea americana Mill) in alloxan induced diabetic rats," Pharmacologyonline. 2010, vol.1, pp.901-908.

20. M.A. Owolabi, H.A.B. Coker and S.I. Jaja, "Bioactivity of the phytoconstituents of the leaves of Persea Americana," J Med Plants Res. vol.4, pp.1130-1135, 2010

21. B.S. Antia, J.E. Okokon and P.A. Okon, "Hypoglycemic activity of aqueous leaf extract of Persea americana Mill," Indian J Pharmacol. vol.37, pp.325-326, 2005

22. A.D. Kinghorn, D.D. Soejarto, N.P.D. Nanayakkara, C.M. Compadre, H.C. Makapugay and J.M. Hovanec-Brown et al., "A Phytochemical Screening Procedure for Sweet Ent-Kaurene Glycosides in the Genus Stevia,” J. Nat. Prod. vol.47, pp.439-444, 1984.

23. N. Masih and B. Singh, "Phytochemical Screening of Some Plants Used in Herbal Based Cosmetic Preparations," In: L. Khemani, M. Srivastava and S. Srivastava, (eds) "Chemistry of Phytopotentials: Health, Energy and Environmental Perspectives," Springer, Berlin, Heidelberg. pp. 111-112, 2012.

24. G. Angajala, P. Pavan and R. Subashini, "One-step biofabrication of copper nanoparticles from Aegle marmelos correa aqueous leaf extract and evaluation of its anti-inflammatory and mosquito larvicidal efficacy,", RSC Advances. vol.4, pp.51459-51470, 2014.

25. G. Angajala, R. Ramya and R. Subashini, "In-vitro anti-inflammatory and mosquito larvicidal efficacy of nickel nanoparticles phytofabricated from aqueous leaf extracts of Aegle marmelos Correa," Acta Tropica. vol.135, pp.19-26, 2014.

\section{AUTHORS PROFILE}

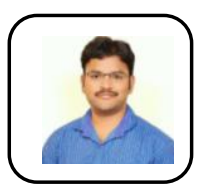

Gangadhara Angajala is working as an Assistan professor in Department of Chemistry at Kalasalingam Academy of Research and Education. He completed his under-graduation in B.Sc with triple major at Government Degree College for Men, Anantapur, Andhra Pradesh and his graduation with specialization in Pharmaceutical Chemistry at Vellore Institute of Technology, Tamil nadu. He obtained his Ph.D with specialization in Organic and Medicinal Chemistry from VIT University. His research area includes synthesis of new quinoline scaffolds with hypoglycemic efficacy by using nanocatalysis.

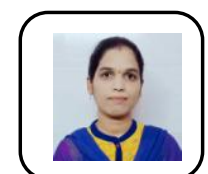

Valmiki Aruna has completed her under-graduation in B.Sc with triple major at Government Degree College for Men, Anantapur, Andhra Pradesh and currently persuing her M.Sc Chemistry at Kalasalingam Academy of Research and Education, Krishnankoil, Tamil Nadu, India.

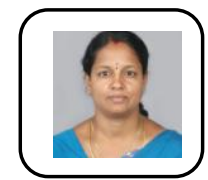

Radhakrishnan Subashini has completed her Ph.D at VIT University, Vellore in 2011. She has done M.Phil at KMCPGS, Pondicherry University, Pondicherry and M.Sc at Annamalai University, Chidambaram. She is currently working as an Assistant Professor at Arignar Anna Government Arts College for Women, Walajapet,

Tamilnadu, India.

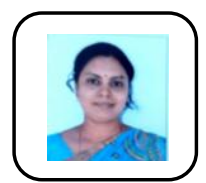

D.Geetha has completed M. Sc in Chemistry discipline from Bharathidasan University, M. Phil., from Annamala University. She completed $\mathrm{Ph}$. D from Jaypee University in 2016. She is currently working as an Assistant professor at Kalasalingam Academy of Research and Education from 2017 onwards. Her field

of interest is bio surfactant. She has published 7 papers in reputed international journals.

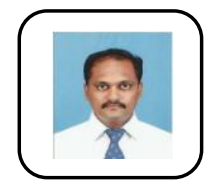

Rajajeyagantha Ramanathan completed his B.Sc. Applied Sciences from Coimbatore Institute of Technology, Coimbatore and M.Sc., Applied Chemistry from National Institute of Technology, Tiruchirappalli. He was awarded "Best Outgoing

Student" with a gold medal in M.Sc. He completed his
Ph.D (Surface Science) under TWAS-CNPq fellowship from Federal University of Rio Grande do Sul, RS, Brazil. 